\title{
TRANSITIVITY PROCESSES IN BON JOVI'S SELECTED SONG LYRICS
}

\author{
Hiace Vega Fernando Siahaan \\ Universitas Darma Agung, Medan, Indonesia \\ hiacevegafernando@yahoo.com
}

Submitted: 31/07/2021

Accepted: 16/08/2021

Publication: 18/08/2021

\begin{abstract}
The focus of this research is to find the usage of the transitivity processes in Bon Jovi's selected song lyrics. This research is descriptive qualitative research. This research aims to discover and examine types of the transitivity processes used in Bon Jovi's selected song lyrics. The source data of this research are the twenty selected song lyrics of Bon Jovi. Meanwhile, the data of this research are the clauses that used transitivity processes in Bon Jovi's selected song lyrics. The data of this research are analyzed by using the interactive model. The result of this research shows that all of the six types of transitivity processes are found in Bon Jovi's selected song lyrics, namely: material processes, mental processes, relational processes, verbal processes, behavioral processes, existential processes. It shows that Bon Jovi, in realizing the song, applied the six types of transitivity processes. From the six types of transitivity processes that are found, the material process is dominantly used in Bon Jovi's selected song lyrics. It indicates that Bon Jovi's selected song lyrics are related to the physical activity that happens in the social phenomena. It is helpful for the readers to know transitivity processes in understanding the message of the song. Besides it, it also gives advantages for the songwriter in writing song lyrics to provide the varieties of wording in the songs.
\end{abstract}

Keywords: transitivity processes, song lyrics, systemic functional linguistics.

\section{Introduction}

A song is one of the sources of entertainment that could be used to brighten a person's mood by listening to pleasant songs. Through song, listeners can obtain information and knowledge by interpreting the words in the lyrics of the song and exploring the meaning contained in the lyrics of the song. Songwriters usually have different lyrics and have different goals. Some songwriters focus their songs on romance, religion, criticism, and so on. In creating song lyrics, a songwriter needs language. As it is known that language is a means of conveying information. This research focuses on the análysis of the transitivity processes used by songwriter of Bon Jovi on each song lyrics created. The transitivity processes are concerned with the realization of the use of verbs in clauses in each song's lyrics.

Halliday (2014) stated that there are six types of transitivity processes, namely: material processes, mental processes, behavioral processes, relational processes, verbal processes, and existential processes. All the processes are related to a verb that is used in clauses. The use of transitivity processes in every field is different from each other, for example, song and speech will have different types of transitivity processes. The language of a song is usually created and written indifferently from the ordinary language in different fields. In other words, some song listeners sometimes have difficulties understanding the meaning or goals of the song as the song is the expression of feelings of the songwriters. As a result, language song analysis is both interesting and necessary to be analyzed.

Bon Jovi is a rock band from Sayreville, New Jersey, United States. This rock band is a famous rock band since 1983 with members are: Jon Bon Jovi as the vocalist, David Bryan as the keyboardist, Tico Torres as the drummer, Phil X as the guitarist, and Hugh McDonald as the Bassist. The reason why the researcher wants to do the analysis of Bon Jovi's selected song lyrics is that is one of the popular rock bands in this world. There are so many song lyrics that 
have been created by Bon Jovi and also there are so many fans of Bon Jovi in this world. The research problems of this study are what are the types of transitivity processes used in Bon Jovi's selected song lyrics and how its realization in each clause in Bon Jovi's selected song lyrics. The value of this research is the readers and the song listeners can be easier understand each lyric in a song that is heard by them. Besides that, the songwriters should be considered the usage of types of transitivity processes in writing song lyrics in order to give an easier understanding for the song listeners.

Some scholars had already conducted researches on transitivity and song analysis ( Zahoor in 2016; Setiawati in 2018; Isti' anah in 2019; Sihura in 2019; Pasaribu in 2020; Yanti in 2020; Afri in 2021 and Fajrin in 2021). There is no single study about the analysis of transitivity in Bon Jovi's songs, as evidenced by the eight studies cited. As a result, this study fills in the gaps and contributes to the understanding of six types of transitivity processes in songs.

\section{Literature Review}

In systemic functional linguistics, the transitivity system is one of the aspects of the ideational function in metafunction. There are three categories of transitivity systems: transitivity process, transitivity participant, and transitivity circumstance. The uses of verb phrases are the realization of the transitivity process. Transitivity participants are realized by the doer and it is affected by the processes then it is usually realized by noun phrases. Meanwhile, transitivity circumstances are the realization of the adjunct component such as adverbial phrases. The clauses of sentences are formed by this transitivity system. Halliday (2014) has identified that there are six types of transitivity processes, namely: material processes, mental processes, relational processes, behavioral processes, verbal processes, existential processes.

Material processes concern with the processes of happening or doing that relates to the human's physical. Mental processes represent the processes of sense that relate to human psychology. Relational process reflects the connection between two entities which is categorized into attributing, identifying, and symbolizing. Behavioral processes are the processes of an entity's behavior and represent psychological or physiological behavior. The act of saying or the process of stating some information is referred to as verbal processes. Existential processes imply the existence of an entity. Table 1 below shows the types of processes, the construing of the processes, and a sample of the processes.

Table 1. Transitivity Processes

\begin{tabular}{|c|c|c|c|}
\hline No. & Types of Processes & Construing & Sample of Verbs \\
\hline 1. & Material & $\begin{array}{l}\text { creating, changing, doing (to), } \\
\text { acting }\end{array}$ & reading, giving, choosing \\
\hline 2. & Mental & seeing, feeling, thinking & $\begin{array}{l}\text { loving, thinking, believing, } \\
\text { knowing, forgetting, } \\
\text { admiring }\end{array}$ \\
\hline 3. & Verbal & saying & $\begin{array}{l}\text { expressing, stating, saying, } \\
\text { telling, pledging }\end{array}$ \\
\hline 4. & Relational & $\begin{array}{l}\text { attributing, } \\
\text { symbolizing }\end{array}$ & $\begin{array}{l}\text { to be, linking verbs, have, } \\
\text { has, own }\end{array}$ \\
\hline 5. & Behavioural & behaving & $\begin{array}{l}\text { smiling, dreaming, staring, } \\
\text { breathing, coughing }\end{array}$ \\
\hline 6. & Existential & existing & to be (is, am, are) \\
\hline
\end{tabular}

Source: Halliday (2014: $213-217)$

\section{Research Method}

This research is descriptive qualitative research. This research is based on systemic functional linguistics, specifically the types of the transitivity processes as part of metafunction in systemic functional linguistics. The analysis of this research is focused on the types of transitivity processes in the song lyrics of Bon Jovi. There are twenty song lyrics in this research, namely: 1) Livin On A Prayer; 2) It's My Life; 3) Always; 4) You Give Love A Bad Name; 5) Bed of Roses; 6) I'll Be There For You; 7) Wanted Dead of Alive; 8) Never Say 
Goodbye; 9) Thank You For Loving Me; 10) Have A Nice Day; 11) Run Away; 12) This Ain't A Love Song; 15) Bad Medicine; 16) Miracle; 17) In These Arms; 18) Story of My Life; 19) Limitless; 20) All About Lovin' You. The data analysis technique used and interactive model data analysis suggested by Miles, Hubberman, and Saldana (2014:10), which is seen in Figure 1 below.

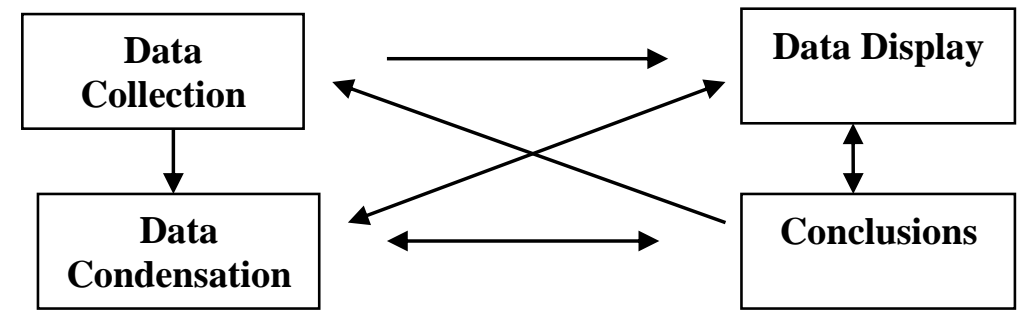

Figure 1. Interactive Model Data Analysis

(Miles, Hubberman \& Saldana, 2014:10)

In investigating the types of transitivity processes in Bon Jovi's selected song lyrics, the four steps of the interactive model data analysis are applied in this research. In conducting the analysis, the four processes are interconnected.

\section{Results and Discussion}

It is found that there are 755 transitivity processes used in the twenty selected song lyrics of Bon Jovi. The occurrences of each type of the transitivity processes used in Bon Jovi's selected song lyrics differ from one another. From the analysis that has been done, it shows that the six types of transitivity processes are realized in the twenty selected song lyrics of Bon Jovi, namely: material processes, mental processes, relational processes, behavioral processes, verbal processes, and existential processes. The occurrences and percentage of each type of transitivity process in the twenty selected song lyrics of Bon Jovi are shown in Table 2 below.

Table 2. Occurrences and Percentage of Types of Transitivity Processes

\begin{tabular}{ccc}
\hline Types of Transitivity Processes & Occurrences of Processes & Percentage \\
\hline Material & 333 & $44,1 \%$ \\
Mental & 190 & $25,2 \%$ \\
Relational & 97 & $12,8 \%$ \\
Verbal & 64 & $8,5 \%$ \\
Behavioral & 51 & $6,8 \%$ \\
Existential & 20 & $2,6 \%$ \\
Total & $\mathbf{7 5 5}$ & $\mathbf{1 0 0}$ \\
\hline
\end{tabular}

Table 2 shows that material processes are the most commonly used with the occurrences of processes is 333 data and the percentage is $44,1 \%$. The second domination is mental processes with the occurrences of processes is 190 data and the percentage is $25,2 \%$. The third domination is relational processes with the occurrences of processes is 97 data and the percentage is $12,8 \%$. The fourth domination is verbal processes with the occurrences of processes is 64 data and the percentage is $8,5 \%$. The fifth domination is behavioral processes with the occurrences of processes is 51 data and the percentage is $6,8 \%$. The sixth domination is existence processes with the occurrences of processes is 20 data and the percentage is $2,6 \%$. According to the findings, Bon Jovi's selected song lyrics pay more attention to the physical activities of a human being (material processes) when confronted with social phenomena followed by processes of seeing, feeling, and thinking (mental processes); processes of connecting from one entity to another entity (relational processes); processes of saying (verbal processes); processes of human's physiological activities (behavioral processes) and the processes of entity's existence (existential processes).

The realization of each type of transitivity process in the twenty selected song lyrics of Bon Jovi is shown in Table 3 below. 
Table 3. Realization of Types of Transitivity Processes

\begin{tabular}{|c|c|c|c|c|c|c|c|}
\hline No. & Song's Title & Material & Mental & Behavioral & Relational & Verbal & Existence \\
\hline 1. & $\begin{array}{l}\text { LIVIN ON A } \\
\text { PRAYER }\end{array}$ & 14 & 2 & - & - & 4 & - \\
\hline 2. & IT'S MY LIFE & 9 & 3 & 4 & 4 & 3 & - \\
\hline 3. & ALWAYS & 22 & 14 & 6 & 9 & 9 & - \\
\hline 4. & $\begin{array}{l}\text { YOU GIVE LOVE } \\
\text { A BAD NAME }\end{array}$ & 19 & - & 1 & 3 & 3 & 1 \\
\hline 5. & BED OF ROSES & 26 & 14 & 7 & 6 & 4 & 2 \\
\hline 6. & $\begin{array}{l}\text { I'LL BE THERE } \\
\text { FOR YOU }\end{array}$ & 13 & 15 & 2 & 7 & 6 & 5 \\
\hline 7. & $\begin{array}{l}\text { WANTED DEAD } \\
\text { OF ALIVE }\end{array}$ & 11 & 2 & 4 & 5 & 1 & - \\
\hline 8. & $\begin{array}{l}\text { NEVER SAY } \\
\text { GOODBYE }\end{array}$ & 13 & 10 & 2 & 2 & 9 & 1 \\
\hline 9. & $\begin{array}{l}\text { THANK YOU } \\
\text { FOR LOVING ME }\end{array}$ & 16 & 14 & 2 & 3 & 9 & 1 \\
\hline 10. & $\begin{array}{l}\text { HAVE A NICE } \\
\text { DAY }\end{array}$ & 12 & 8 & 6 & 3 & 3 & 1 \\
\hline 11. & RUN AWAY & 13 & 7 & 2 & 4 & 1 & 1 \\
\hline 12. & $\begin{array}{l}\text { THIS AIN'T A } \\
\text { LOVE SONG }\end{array}$ & 17 & 12 & 3 & 7 & 2 & 1 \\
\hline 13. & HALLELUJAH & 18 & 12 & 1 & 10 & - & 2 \\
\hline 14. & $\begin{array}{l}\text { BORN TO BE MY } \\
\text { BABY }\end{array}$ & 25 & 6 & 3 & 3 & - & 1 \\
\hline 15. & BAD MEDICINE & 37 & 24 & - & 17 & 1 & - \\
\hline 16. & MIRACLE & 15 & 9 & 2 & 1 & 3 & - \\
\hline 17. & IN THESE ARMS & 8 & 12 & 1 & 1 & 3 & 3 \\
\hline 18. & $\begin{array}{l}\text { STORY OF MY } \\
\text { LIFE }\end{array}$ & 14 & 6 & - & 10 & 1 & - \\
\hline 19. & LIMITLESS & 16 & 4 & 3 & - & - & - \\
\hline 20. & $\begin{array}{l}\text { ALL ABOUT } \\
\text { LOVIN' YOU }\end{array}$ & 15 & 16 & 2 & 2 & 2 & 1 \\
\hline & TOTAL & 333 & 190 & 51 & 97 & 64 & 20 \\
\hline
\end{tabular}

Table 3 shows that from the twenty selected song lyrics of Bon Jovi, the realization of the types of transitivity processes are different in each selected song lyrics. Song's title 'LIVIN ON A PRAYER' shows that only three types of transitivity processes in the song lyrics, they are: material processes, mental processes, and verbal processes. Song titles 'IT'S MY LIFE', 'ALWAYS', 'WANTED DEAD OF ALIVE', and 'MIRACLE' show only five types of transitivity processes in the song lyrics, namely: material processes, mental processes, behavioral processes, relational processes, and verbal processes. The song title 'YOU GIVE LOVE A BAD NAME' shows only five types of transitivity processes in the song lyrics, namely: material processes, behavioral processes, relational processes, verbal processes, and existence processes. Song titles 'HALLELUJAH' and 'BORN TO BE MY BABY' show only five types of transitivity processes in the song lyrics, namely: material processes, mental processes, behavioral processes, relational processes, and existence processes. Song's titles 'BAD MEDICINE' and 'STORY OF MY LIFE' show only four types of transitivity processes in the song lyrics, namely: material processes, mental processes, relational processes, and verbal processes. Song's title 'LIMITLESS' shows only three types of transitivity processes in the song lyrics, namely: material processes, mental processes, and behavioral processes. Meanwhile, the song's titles 'BED OF ROSES', 'I'LL BE THERE FOR YOU', 'NEVER SAY GOODBYE', 'THANK YOU FOR LOVING ME', 'HAVE A NICE DAY', 'RUN AWAY', 'THIS AIN'T A LOVE SONG', 'IN THESE ARMS' and 'ALL ABOUT LOVIN' YOU' shows 
that all the six types of the transitivity processes in the song lyrics, they are: material processes, mental processes, behavioral processes, relational processes, verbal processes, and existential processes. Table 4 shows some of the examples of the transitivity processes analysis in each song's lyrics.

Table 4. Examples of Transitivity Processes Analysis

\begin{tabular}{|c|c|c|}
\hline Song's Title & Clause of the Song Lyrics & $\begin{array}{c}\text { Types of } \\
\text { Transitivity } \\
\text { Processes } \\
\end{array}$ \\
\hline \multirow[t]{3}{*}{ LIVIN ON A PRAYER } & $\begin{array}{l}\text { Tommy used to work on the docks } \\
\text { Union }\end{array}$ & Material processes \\
\hline & Tommy whispers; Baby it's okay & Verbal processes \\
\hline & When she cries in the night & Mental processes \\
\hline \multirow[t]{5}{*}{ IT'S MY LIFE } & I did it my way & Material processes \\
\hline & You're gonna hear my voice & Mental processes \\
\hline & But I ain't gonna live forever & $\begin{array}{l}\text { Behavioral } \\
\text { processes }\end{array}$ \\
\hline & And it is now or never & $\begin{array}{l}\text { Relational } \\
\text { processes }\end{array}$ \\
\hline & When I shout it out loud & Verbal processes \\
\hline \multirow[t]{5}{*}{ ALWAYS } & That this old dog kicked up & Material processes \\
\hline & And I will love you baby & Mental processes \\
\hline & Some that made us laugh & $\begin{array}{l}\text { Behavioral } \\
\text { processes }\end{array}$ \\
\hline & It is nothing but some feelings & $\begin{array}{l}\text { Relational } \\
\text { processes }\end{array}$ \\
\hline & I can't sing a love song & Verbal processes \\
\hline YOU GIVE LOVE A BAD & You play your game & Material processes \\
\hline \multirow[t]{4}{*}{ NAME } & You can't break free & $\begin{array}{l}\text { Behavioral } \\
\text { processes }\end{array}$ \\
\hline & You are a loaded gun & $\begin{array}{l}\text { Relational } \\
\text { processes }\end{array}$ \\
\hline & You promise me heaven & Verbal processes \\
\hline & There is nowhere to run & $\begin{array}{l}\text { Existential } \\
\text { processes }\end{array}$ \\
\hline \multirow[t]{6}{*}{ BED OF ROSES } & Sitting here wasted & Material processes \\
\hline & As I dream about movies & Mental processes \\
\hline & I'll sleep on a bed of nails & $\begin{array}{l}\text { Behavioral } \\
\text { processes }\end{array}$ \\
\hline & For it is you & $\begin{array}{l}\text { Relational } \\
\text { processes }\end{array}$ \\
\hline & While we're talking & Verbal processes \\
\hline & She is still in my bed & $\begin{array}{l}\text { Existential } \\
\text { processes }\end{array}$ \\
\hline \multirow[t]{6}{*}{ I'LL BE THERE FOR YOU } & $\begin{array}{l}\text { And now you're swimming for the } \\
\text { shore }\end{array}$ & Material processes \\
\hline & You know my hands are dirty & Mental processes \\
\hline & When you breathe & $\begin{array}{l}\text { Behavioral } \\
\text { processes }\end{array}$ \\
\hline & When you were down & $\begin{array}{l}\text { Relational } \\
\text { processes }\end{array}$ \\
\hline & I swear to you & Verbal processes \\
\hline & I wasn't there & $\begin{array}{l}\text { Existential } \\
\text { processes }\end{array}$ \\
\hline WANTED & I'd drive all night & Material processes \\
\hline
\end{tabular}




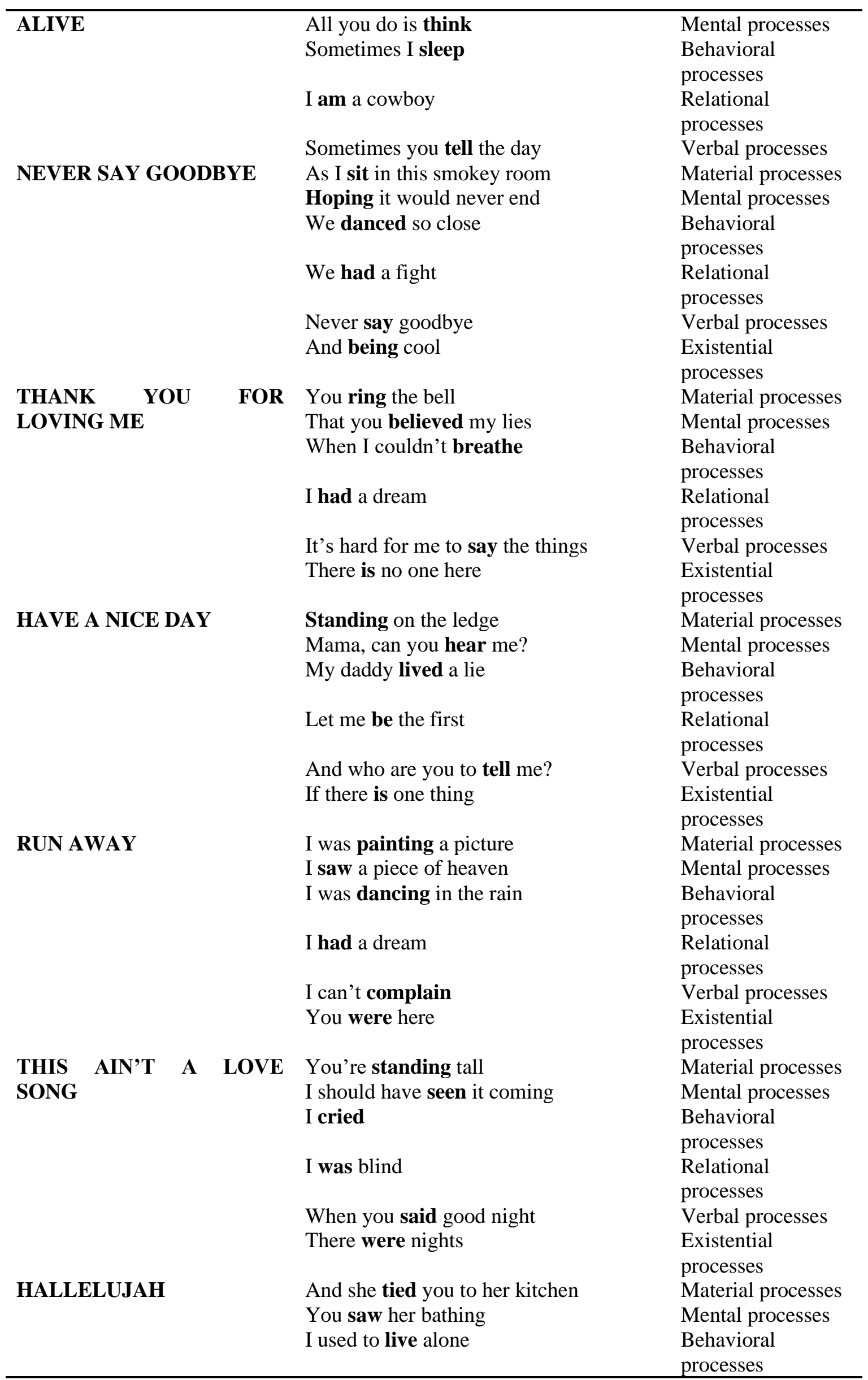




\begin{tabular}{|c|c|c|}
\hline & It is a broken Hallelujah & $\begin{array}{l}\text { Relational } \\
\text { processes }\end{array}$ \\
\hline & There is a God above & $\begin{array}{l}\text { Existential } \\
\text { processes }\end{array}$ \\
\hline \multirow[t]{5}{*}{ BORN TO BE MY BABY } & We worked all day & Material processes \\
\hline & God would know the reasons & Mental processes \\
\hline & In my heart till the day that I die & $\begin{array}{l}\text { Behavioral } \\
\text { processes }\end{array}$ \\
\hline & It is a bumpy ride & $\begin{array}{l}\text { Relational } \\
\text { processes }\end{array}$ \\
\hline & There is a chance & $\begin{array}{l}\text { Existential } \\
\text { processes }\end{array}$ \\
\hline \multirow[t]{4}{*}{ BAD MEDICINE } & Shake it up just like bad medicine & Material processes \\
\hline & What you get for falling in love & Mental processes \\
\hline & Bad medicine is what I need & $\begin{array}{l}\text { Relational } \\
\text { processes }\end{array}$ \\
\hline & $\begin{array}{l}\text { And I got all the symptoms count 'em } \\
1,2,3\end{array}$ & Verbal processes \\
\hline \multirow[t]{5}{*}{ MIRACLE } & They drive you right back down & Material processes \\
\hline & I know you think you're going crazy & Mental processes \\
\hline & A man has to die & $\begin{array}{l}\text { Behavioral } \\
\text { processes }\end{array}$ \\
\hline & And I know the dam is busted & $\begin{array}{l}\text { Relational } \\
\text { processes }\end{array}$ \\
\hline & They promised us truth & Verbal processes \\
\hline \multirow[t]{6}{*}{ IN THESE ARMS } & They burn with fire & Material processes \\
\hline & Baby I want you like the roses & Mental processes \\
\hline & I'd die to have you & $\begin{array}{l}\text { Behavioral } \\
\text { processes }\end{array}$ \\
\hline & And these were our words & $\begin{array}{l}\text { Relational } \\
\text { processes }\end{array}$ \\
\hline & I'd tell you & Verbal processes \\
\hline & If you were in these arms & $\begin{array}{l}\text { Existential } \\
\text { processes }\end{array}$ \\
\hline \multirow[t]{4}{*}{ STORY OF MY LIFE } & And I write it every day & Material processes \\
\hline & You know I'm not all right & Mental processes \\
\hline & That is the story of my life & $\begin{array}{l}\text { Relational } \\
\text { processes }\end{array}$ \\
\hline & I swear & Verbal processes \\
\hline \multirow[t]{3}{*}{ LIMITLESS } & Everybody wake up & Material processes \\
\hline & You know the song & Mental processes \\
\hline & Better not forget to breathe & $\begin{array}{l}\text { Behavioral } \\
\text { processes }\end{array}$ \\
\hline \multirow[t]{6}{*}{ ALL ABOUT LOVIN' YOU } & And all the things I didn't do & Material processes \\
\hline & Baby, I see something new & Mental processes \\
\hline & I don't wanna sleep tonight & $\begin{array}{l}\text { Behavioral } \\
\text { processes }\end{array}$ \\
\hline & You are always my best friend & $\begin{array}{l}\text { Relational } \\
\text { processes }\end{array}$ \\
\hline & Ask me how we've come this far & Verbal processes \\
\hline & You were there to pull me through & $\begin{array}{l}\text { Existential } \\
\text { processes }\end{array}$ \\
\hline
\end{tabular}




\section{Conclusion}

It is determined that there are 755 transitivity processes used in numerous occurrences of each type of the transitivity processes from the twenty selected song lyrics of Bon Jovi. It has been determined that nine of the twenty song lyrics chosen by Bon Jovi used all six types of transitivity processes, whereas the other song lyrics used only some of the transitivity processes. Based on the findings of this research, material processes are dominantly used, followed by mental processes, relational processes, verbal processes, behavioral processes, and existential processes. This means that Bon Jovi's songwriter is most concerned with describing physics activities in the song lyrics, such as work, running, standing, and so on through the material processes. The message of Bon Jovi's selected song lyrics is expressed not only through material processes but also through mental processes such as love, see, hear, need, cry and so on; relational processes that realize by the using of 'to be' such as: be, is, was; verbal processes that realize by a shout, said, calling, sing; behavioral processes that are realized by a laugh, die, sleep and so on. Meanwhile, existential processes are the types of transitivity processes that are rarely used in the selected song lyrics of Bon Jovi. Existential processes are realized by the using of verbs 'be' to show the existent of one entity for example there is, being cool, you were here, and so on. In other words, it is concluded that the realization of each type of the transitivity processes in selected song lyrics of Bon Jovi is diverse. This is to provide the variation of the wording used in each song's lyrics to entertain the song listeners, particularly the fans of Bon Jovi.

\section{References}

Afri, Evan \& Intan Maulina. (2021). Analysis of Derivational and Inflectional Morpheme in Song's Lyrics of Adele Album. International Journal of English and Applied Linguistics, Vol. 99 | Number 99 | Month Year | E-ISSN : 9999-999x | DOI: doi.org/ijeal.v1n1.983.

Bartlett, Tom \& O'Grady, Gerrad. (2017). The Routledge Handbook of Systemic Functional Linguistics. New York: Oxford University Press, Inc.

Bloor, Thomas \& Bloor, Meriel. (2004). The Functional Analysis of English. New York: Oxford University Press, Inc.

Eggins, Suzanne. (2004). An Introduction Systemic Functional Linguistics. London \& New York: Continuum.

Fajrin, Maudy Yaser \& Parmawati, Aseptiana. (2021). An Analysis of Figurative Language Found in Song of Bruno Mars Entitled 'Grenade'. Professional Journal of English Education (PROJECT). Volume. 4, No. 4, July 2021.

Harbi, S., Abdul Jabar, M. S., Md. Nor, A.N. \& Muhammad Isa, N. 2019. International Journal of Language Education and Applied Linguistics (IJLEAL), Vol. 9, No. 1, 45-54.

Halliday, M.A.K. (1994). An Introduction To Functional Grammar, Second Ed. London: Edward Arnold.

Halliday, M.A.K \& Matthiessen, CM.I.M. (2004). An Introduction To Functional Grammar, Third Ed. London: Edward Arnold.

Halliday, M.A.K \& Matthiessen, C.M.I.M. (2014). Halliday's Introduction To Functional Grammar, Fourth Ed. London: Edward Arnold.

Isti'anah, Arina. (2019). Transitivity Analysis of Afghan Women in Asne Seirstad's The Bookseller of Kabul. Lingua. Vol. 14, No. 12, December 2019.

Martin, J.R \& D. Rose. (2003). Working With Discourse: Meaning Beyond the Clause. London: Continuum.

Miles, Matthew B, Huberman, Michael A \& Saldana, J. (2014). Qualitative Data Analysis, $3^{\text {rd }}$ Edition. California: SAGE Publications. 
Pasaribu, Arsen Nahum. (2020). Transitivity Analysis of Nahum Situmorang's Tradiditional Song Lyrics. International Conference on Creativity \& Technology (NICCT). DOI 10.4108/eai.20-9-2019.2296586.

Saragih, Amrin. (2011). Semiotik Bahasa: Tanda, Penanda dan Petanda Dalam Bahasa. Medan: Unimed Press.

Setiawati, Wilya \& Maryani. (2018). An Analysis of Figurative Language in Taylor Swift's Song Lyrics. Professional Journal of English Education (PROJECT). Vol. 01, No. 03, May 2018.

Sihura, Meltarina. (2019). Transitivity Processes in Frozen Movie: A Study of Systemic Functional Grammar. International Journal of Systemic Functional Linguistics 2 (2), 2019, 79-85.

Yanti, Ni Wayan Kintya Tista. (2020). Processes Types of Transitivity System in the Ritual Teks of Tawur Sasih Kesanga in Desa Adat Kuta. e-Journal of Linguistics Vol. 14, No.2, July 2020, pages: 257-267.

Zahoor, Mehwish \& Janjua Fuzia. (2016). Character Construction in Tributive Songs: Transitivity Analysis of the Song 'I Am Malala'. TRAMES. 20 (70/65), page 201-213. 